\title{
PEDIGREE SELECTION IN BREAD WHEAT UNDER WATER DEFICIT FOR YIELD IN TOSHKA CONDITIONS
}

\author{
Nassar, Saad M.A. \\ Department of Genetic Resources, Desert Research Center, El- \\ Matareya, Cairo, Egypt. \\ E-mail:saad3a@yahoo.com
}

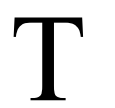

he present work aimed to study the effect of two cycles of pedigree selection for highly grain yield in two segregating populations of wheat under water stress, during the two winter seasons of 2015/2016 and 2016/2017 at Toshka Research Station, Desert Research Center, Aswan, Egypt. The water treatments were 100 and $67 \%$ of the irrigation requirements of wheat in Toshka as normal and drought condition, respectively. A transgressive segregation in both populations for all studied traits inducted the suitability of those material for pedigree selections. The genetic advanced for grain yield/plant and its components were greater in population 2 than in population 1 in the first cycle in pedigree selection. Highly significant differences among the selected families for all the studies traits were observed in both populations under normal and drought conditions. After one cycles of selection, the broad sense heritability was very high for most traits and reached 77.79 and $92.02 \%$ for grain yield/plant under normal irrigation, while were 87.53 and $93.12 \%$ under drought stress in population 1 and population 2, respectively. Two cycles of pedigree selection for grain yield/plant was enough to detect the best families and could be performed in the early segregating generations. It could be concluded that single trait selection was efficient to improve the selection criteria in these populations. These genotypes could be sources for drought tolerance.

Keywords: Triticum aestivum, pedigree selection, genotypic and phenotypic variation, heritability, observed gain from selection

In developing countries, wheat (Triticum aestivum L.) is one of the most important crops as it can be considered as the main source of carbohydrate. Besides being a high carbohydrate food, wheat contains

The $1^{\text {st }}$ Scientific Conference of Plant Genetic Resources Department, Ecology and Dry Lands Agriculture Division, Desert Research Center "Plant Genetic Resources and Sustainable Development Under Egyptian Desert Conditions" 13-16 November, 2019, Sharm El-Sheikh, South Sinai, Egypt 
valuable protein, minerals, and vitamins. In food industry, wheat is necessary to produce breads, rolls, crackers, cookies, etc. In Egypt, there is a big gap between needs and production of wheat. To fill up this gap, the imported amount reached about $49.80 \%$ of the total amount of wheat consumption (FAO, 2018). Although wheat is the most cultivation area occupies more than $44.41 \%$ of cereals cultivation area (FAO, 2018). In the last two decades, Egypt population increased by about 84\% (FAO, 2018), while the cultivated land and water resources remains the same.

By 2025 , more than 2.8 billion people in 48 countries will face water stress or water scarcity conditions and Egypt one of these countries (UNECA, 2000). Drought tolerance is the ability of a variety to remain relatively more productive than others under limited water conditions (Blum et al., 1983). Drought is the main environmental abiotic stress, which have devastating effects on wheat productivity. Wheat production is adversely affected by drought in $50 \%$ of the developed area and in $70 \%$ of the developing countries (Trethowan and Pfeiffer, 2000). Hence, the introduction of varieties with improved tolerance to drought stress has been one of the most important goals of crop improvement programs (Ludlow and Muchow, 1990).

To start a proper wheat breeding program for improving drought tolerance, the source populations should possess a great amount of genetic variability amenable for efficient selection. Selection from established cultivars would rarely isolate a new genotype (Poehlman and Sleper, 1995). Selection from segregating generations of wheat hybrid combinations succeeded to develop new genotypes that possess adaptive traits of drought tolerance, such as early maturity (Menshawy, 2007 and Al-Naggar et al., 2007), glaucosness (Al-Naggar et al., 2004 and Al-Bakry, 2007), high water use efficiency (Farshadfar et al., 2011) and high grain yield/plant under water deficit conditions (Al-Naggar and Shehab El-Deen, 2012). To practice an efficient selection program for drought tolerance in segregating generations of wheat hybrids, the additive genetic variance should play a major role in the inheritance of such adaptive traits.

The present work aimed to study the effect of two cycles of pedigree selection for highly grain yield/plant in two segregating populations of wheat under water stress at Toshka region. The main objective of the present investigation was to develop new wheat genotypes (transgressive segregates) of high grain yield/plant under water stress conditions. The detailed objectives were to (i) estimate variance components, heritability and expected genetic advance from selection in $\mathrm{F}_{2}$ and $\mathrm{F}_{3}$ crosses under water stress and normal conditions, (ii) evaluate 50 selections along with their parents for drought. Therefore, the present study was conducted to evaluate the response of $F_{3}$ segregating population under water stress condition for yield/plant.

Egyptian J. Desert Res., 69, Special Issue, 1-18 (2019) 


\section{MATERIALS AND METHODS}

The present work was carried out at Toshka Station, Desert Research Center, Aswan, Egypt, during the two winter seasons of 2015/2016 and 2016/2017. Drip irrigation system was applied in these experiments. The irrigation requirements in the reclaimed soils was $1800 \mathrm{~m}^{3}$ per feddan (1 feddan $=4200 \mathrm{~m}^{2}$ ) during the season used as a control, while the drought stress was $67 \%\left(1200 \mathrm{~m}^{3}\right)$ of the total irrigation requirement. The monthly mean of temperature, relative humidity and wind speed at Toshka region during these seasons are presented in table (1). While, soil of the experimental site was sandy.

Table (1). Monthly average weather data at Toshka during 2015/2016 and 2016/2017 growing seasons.

\begin{tabular}{|c|c|c|c|c|c|c|}
\hline $\begin{array}{l}\text { Month } \\
\text { (Mean) }\end{array}$ & $\begin{array}{c}\text { Average } \\
\mathrm{T}_{\dagger}^{\dagger} \\
\left({ }^{\circ} \mathrm{C}\right)\end{array}$ & $\begin{array}{c}\operatorname{Min} . \mathbf{T} \dagger \\
\left({ }^{\circ} \mathbf{C}\right)\end{array}$ & $\begin{array}{c}\operatorname{Max} . \mathbf{T}^{\dagger} \dagger \\
\left({ }^{\circ} \mathbf{C}\right)\end{array}$ & $\begin{array}{c}\text { R.H. } \\
\%\end{array}$ & $\begin{array}{l}\text { W.S.» } \\
\mathbf{k m} / \mathbf{h}\end{array}$ & $\begin{array}{c}\text { Rainfall } \\
\text { amount } \\
(\mathbf{m m})\end{array}$ \\
\hline \multicolumn{7}{|c|}{ 2015/2016 season } \\
\hline November 2015 & 23.12 & 16.11 & 30.17 & 46.28 & 14 & 0 \\
\hline December 2015 & 18.43 & 11.76 & 25.25 & 44.51 & 17 & 0 \\
\hline January 2016 & 16.50 & 9.42 & 23.77 & 40.70 & 12 & 0 \\
\hline February 2016 & 18.34 & 10.53 & 26.16 & 44.18 & 19 & 0 \\
\hline March 2016 & 22.17 & 14.12 & 30.28 & 48.21 & 22 & 0 \\
\hline April 2016 & 27.13 & 18.80 & 35.47 & 50.67 & 18 & 0 \\
\hline May 2016 & 31.29 & 23.25 & 39.13 & 46.80 & 16 & 0 \\
\hline \multicolumn{7}{|c|}{$2016 / 2017$ season } \\
\hline November 2016 & 25.43 & 17.72 & 33.19 & 50.91 & 15 & 0 \\
\hline December 2016 & 21.01 & 13.41 & 28.79 & 48.46 & 19 & 0 \\
\hline January 2017 & 19.47 & 11.12 & 28.05 & 48.03 & 14 & 0 \\
\hline February 2017 & 20.17 & 11.58 & 28.78 & 48.60 & 21 & 0 \\
\hline March 2017 & 25.27 & 16.10 & 34.52 & 54.96 & 25 & 0 \\
\hline April 2017 & 26.70 & 16.14 & 33.26 & 59.79 & 21 & 0 \\
\hline Мay 2017 & 30.74 & 22.70 & 38.78 & 51.48 & 18 & 0 \\
\hline
\end{tabular}

\section{Genetic Materials}

Two cycles of pedigree selection were achieved for grain yield. The genetic materials were the $F_{2}$ and $F_{3}$ of two populations of bread wheat (Triticum asetivum L.). The first population (pop. 1) stemmed from the cross (ICARDA 2×ICARDA 5) and the second population (pop. 2) stemmed from the cross (ICARDA $1 \times$ Gemmeza 7). The pedigree and release of the parental varieties are shown in table (2). Growing seasons, planting dates, genetic materials and experimental design were as follows: 


\begin{tabular}{llll}
\hline Season & Date & Generation & Experimental design \\
\hline $2015 / 2016$ & $5 / 11 / 2015$ & $\mathrm{~F}_{2}$ & Non-replicated \\
$2016 / 2017$ & $2 / 11 / 2016$ & $\mathrm{~F}_{3}$ & RCBD with three replications \\
\hline
\end{tabular}

Table (2). The pedigree of the parental varieties.

\begin{tabular}{cccc}
\hline No. & Entry name & Pedigree & Origin \\
\hline $\mathbf{1}$ & ICARDA 1 & CGSS02Y00144S-099M-099Y-099M-47Y-0B & ICARDA \\
$\mathbf{2}$ & ICARDA 2 & ICB98-0771-0AP & ICARDA \\
$\mathbf{3}$ & ICARDA 5 & ICB97-1207-0AP & ICARDA \\
$\mathbf{4}$ & Gemmeza 7 & CMH74A.630/5x//Seri82/3/Agent & Egypt \\
\hline
\end{tabular}

\section{Season of $2015 / 2016 ; F_{2}$ - generation}

The two aforementioned populations in the $\mathrm{F}_{2}$ - generation were sown in spaced plants; each in 7 rows, $4 \mathrm{~m}$ long, $30 \mathrm{~cm}$ apart and $10 \mathrm{~cm}$ between hills within a row. The parents were sown; each in two rows. The recommended cultural practices for wheat production were adopted throughout the two growing seasons. The following characteristic were recorded on 250 guarded plants from each population, and 10 plants from each parent. The recorded characters were days to heading (DH), plant height $(\mathrm{PH})$, number of spikes/plant (NSPP), spike length (SL), grain yield/spike (GYPS), number of grains/spike (NGPS), biological yield/plant (BYPP), grain yield/plant (GYPP) and 100-grain weight (100-GW).

After harvest, ten grains from each of the 250 plants from Pop. 1 and pop. 2 were bulked to give an unselected bulk sample for each population. Grains of the best 25 plants for grain yield/plant from each population were saved.

\section{Season of $2016 / 2017, F_{3}$ - generation}

The $25 \mathrm{~F}_{3}$-families along with the unselected bulk sample and the two parents were sown in two separated experiment under normal irrigation and drought stress in RCBD with three replications for each population separately (Gomez and Gomez, 1984). The plot size was two rows as in the previous season. The characters were recorded as in the previous season as an average of ten guarded plants from each family.

\section{Statistical Analysis}

Estimates of genotypic and phenotypic variances as well as heritability broad sense were calculated from EMS components of the selected families as presented in table (3).

Egyptian J. Desert Res., 69, Special Issue, 1-18 (2019) 
Table (3). The form of analysis of variance and mean squares expectations.

\begin{tabular}{lccc} 
Source of variation & d.f. & M.S. & $\begin{array}{c}\text { Expected mean } \\
\text { squares variance }\end{array}$ \\
\hline Replications & $\mathrm{r}-1$ & $\mathrm{M}_{3}$ & $\sigma^{2} \mathrm{e}+\mathrm{g} \sigma^{2} \mathrm{r}$ \\
Entries & $\mathrm{g}-1$ & $\mathrm{M}_{2}$ & $\sigma^{2} \mathrm{e}+\mathrm{r} \sigma^{2} \mathrm{~g}$ \\
Error & $(\mathrm{r}-1)(\mathrm{g}-1)$ & $\mathrm{M}_{1}$ & $\sigma^{2} \mathrm{e}$ \\
\hline
\end{tabular}

Where: $r$ and $g$ are number of replications and genotypes, respectively. $\sigma^{2} \mathrm{e}$ and $\sigma^{2} g$ are the error variance and genetic variance components; respectively. The phenotypic $\left(\sigma^{2} p\right)$ and genotypic $\left(\sigma^{2} g\right)$ variances were calculated according to the following formulae:

$$
\begin{array}{ll}
\sigma^{2} \mathbf{p}=\sigma^{2} \mathbf{g}+\boldsymbol{\sigma}^{2} \mathbf{e} / \mathbf{r} & \sigma^{2} \mathbf{g}=\left(\mathbf{M}_{2}-\mathbf{M}_{1}\right) / \mathbf{r}
\end{array}
$$

Two separate analysis of variance were done. The first includes the entries (25 selected families along with the bulk samples and the two parents) to measure the variability and the significance of the observed gain. The second include the selected families only to calculate phenotypic (PCV), genotypic (GCV) coefficients of variability and heritability estimates in broad sense.

\section{Heritability}

The following equation was used to estimate heritability in broad sense.

$$
(H)=\left(\sigma^{2} g / \sigma^{2} p\right) \times 100
$$

The phenotypic and genotypic coefficients of variation were estimated using the formula developed by Burton (1952).

- The phenotypic coefficient of variability $(\mathrm{PCV})=(\sigma \mathrm{p} / \bar{X}) \times 100$.

- The genotypic coefficient of variability $(\mathrm{GCV})=(\sigma \mathrm{g} / \bar{X}) \times 100$.

Comparisons between means were calculated using Revised L.S.D, was calculated using the formula developed by Al-Rawi and Khalafalla (1980).

\section{RESULTS AND DISCUSSION}

\section{The Estimation of the Base Population ( $F_{2}$ Plants)}

Results in tables (4 and 5) show that grain yield/plant (GYPP) ranged from 4.88 to $27.20 \mathrm{~g}$ with an average of $12.57 \mathrm{~g}$ for pop. 1 and in pop. 2 it ranged from 5.85 to 32.33 with an average of $13.11 \mathrm{~g}$. The range in pop. 1 and pop. 2 in grain yield/plant in the $F_{2}$ generation fell outside the range of their respective parents, reflecting high level of heterozygosity and/or transgressive segregation in both populations. This indicates the feasibility of selection for yield. Variation coefficient (CV\%) were 26.20 and $31.10 \%$ for pop. 1 and pop. 2 , respectively. Phenotypic variance $(\sigma 2 p)$ were 10.85 and 16.62 , while genotypic variance $\left(\sigma^{2} g\right)$ was 10.56 and 16.42 for pop. 1 and pop. 2 , respectively. The low percentage of phenotypic variability 
$\left(\sigma^{2} p\right)$ of the parents was the estimation of the environmental variance, and that reflects the homozygosity, purity and stability of the parents in each population.

The phenotypic $\left(\sigma^{2} p\right)$ and genotypic $\left(\sigma^{2} g\right)$ variances of grain yield/plant (GYPP) in pop. 2 were close, while the heritability in broad sense $\left(\mathrm{H}^{2} \mathrm{~b} \%\right)$ were 97.27 for pop. 1 and $98.80 \%$ for pop. 2. Expected genetic advance $(\Delta G)$ were 5.61 and $7.05 \%$ for pop. $1\left(F_{2}\right.$ plants $)$ and pop. $2\left(F_{2}\right.$ plants), respectively. The percentage between $\Delta \mathrm{G}$ and mean were 44.60 and $53.76 \%$ in pop. 1 and pop. 2, respectively. These results are in agreement with those reported by El-Morshidy et al. (2010) and Ahmed et al. (2014).

Table (4). Means, maximum and minimum values, phenotypic $\left(\sigma^{2} p\right)$ and genotypic $\left(\sigma^{2} \mathrm{~g}\right)$ variances, variation coefficient $(\mathrm{CV} \%)$, heritability $\left(\mathrm{H}^{2} \mathrm{~b} \%\right)$ and expected genetic advance $(\Delta \mathrm{G})$ of the base pop. $1\left(\mathrm{~F}_{2}\right)$ and its parents for all studied traits (season 2015/2016).

\begin{tabular}{|c|c|c|c|c|c|c|c|c|c|}
\hline Pop. 1 & DH & PH & NSPP & SL & GYPS & NGPS & BYPP & GYPP & 100-GW \\
\hline \multirow{2}{*}{ Means $\pm \mathrm{SE}$} & 70.22 & 68.69 & 6.08 & 10.43 & 2.46 & 57.94 & 30.13 & 12.57 & 4.28 \\
\hline & \pm 0.53 & \pm 0.68 & \pm 0.09 & \pm 0.10 & \pm 0.03 & \pm 0.55 & \pm 0.51 & \pm 0.21 & \pm 0.04 \\
\hline Max. & 93.00 & 96.25 & 11.78 & 14.38 & 3.79 & 85.42 & 55.40 & 27.20 & 5.77 \\
\hline Min. & 59.00 & 43.26 & 2.41 & 6.18 & 1.51 & 37.39 & 12.03 & 4.88 & 2.78 \\
\hline CV \% & 12.04 & 15.70 & 23.18 & 15.44 & 18.04 & 14.92 & 26.74 & 26.20 & 16.15 \\
\hline$\sigma^{2} \mathrm{~g}$ & 71.10 & 114.81 & 1.87 & 2.55 & 0.19 & 70.91 & 61.01 & 10.56 & 0.47 \\
\hline$\sigma^{2} p$ & 71.52 & 116.34 & 1.98 & 2.59 & 0.20 & 74.71 & 3 & 5 & 8 \\
\hline 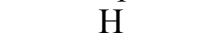 & 99.42 & 98.68 & 94.12 & 98.29 & 95.39 & 94.91 & 93.97 & 97.27 & 98.14 \\
\hline$\Delta \mathrm{G}$ & 14.71 & 18.63 & 2.32 & 2.77 & 0.74 & 14.36 & 13.25 & 5.61 & 1.19 \\
\hline$\Delta \mathrm{G} /$ Mean $(\%)$ & 20.95 & 27.12 & 3.18 & 26.56 & 30.12 & 24.78 & 43.98 & 44.60 & 077 \\
\hline \multicolumn{10}{|l|}{ ICARDA 2} \\
\hline \multirow{2}{*}{ Means $\pm \mathrm{SE}$} & 64.00 & 76.47 & 6.20 & 11.03 & 1.75 & 42.30 & 30.70 & 10.82 & 4.1 \\
\hline & \pm 0.26 & \pm 0.20 & \pm 0.11 & \pm 0.03 & \pm 0.01 & \pm 0.47 & \pm 0.49 & \pm 0.16 & \pm 0.03 \\
\hline Max & 65.00 & 77.00 & 6.50 & 11.10 & 1.79 & 44.40 & 32.70 & 11.45 & 4.25 \\
\hline & 0 & 75.60 & & 10.90 & 1.69 & 41.06 & 28.90 & 10.20 & 3 \\
\hline CV \% & 1.28 & 0.81 & 5.74 & 0.85 & 2.46 & 3.53 & 5.07 & 4.72 & 2.20 \\
\hline$\sigma^{2} p$ & 0.67 & 0.38 & 0.13 & 0.01 & 0.002 & 2.23 & 2.43 & 0.26 & 0.01 \\
\hline \multicolumn{10}{|l|}{ ICARDA 5} \\
\hline \multirow{2}{*}{ Means $\pm \mathrm{SE}$} & 67.50 & 72.64 & 5.10 & 11.70 & 2.29 & 48.16 & 30.40 & 11.63 & 4.75 \\
\hline & $\operatorname{sen}^{2}$ & \pm 0.52 & \pm 0.10 & \pm 0.09 & \pm 0.04 & \pm 0.73 & & & \\
\hline M & 6800 & 74.80 & 5.50 & 11.90 & 2.42 & 50.01 & 33.50 & 12.34 & 4.88 \\
\hline Min. & 67.00 & 70.83 & 4.70 & 11.30 & 2.11 & 44.89 & 27.90 & 10.93 & 4.65 \\
\hline CV \% & 0.6 & 2.26 & 6.4 & 2.42 & 5.5 & 4.81 & 7.65 & 4.95 & 2.05 \\
\hline$\sigma^{2} p$ & 0.17 & 2.69 & 0.11 & 0.08 & 0.02 & 5.37 & 5.41 & 0.33 & 0.009 \\
\hline
\end{tabular}

$\Delta \mathbf{G}=$ Expected genetic advance from selection $10 \%$ superior plants. 
Table (5). Means, phenotypic variance $\left(\sigma^{2} \mathrm{p}\right)$, genotypic variance $\left(\sigma^{2} \mathrm{~g}\right)$, phenotypic coefficient $(\mathrm{CV})$, heritability in broad sense $(\mathrm{H})$ and expected genetic advance $(\Delta \mathrm{G})$ of the base pop. $2\left(\mathrm{~F}_{2}\right)$ and its parents of the studied traits (season 2015/2016).

\begin{tabular}{|c|c|c|c|c|c|c|c|c|c|}
\hline Pop. 2 & DH & PH & NSPP & SL & GYPS & NGPS & BYPP & GYPP & 100-GW \\
\hline \multirow{2}{*}{ Means $\pm \mathrm{SE}$} & 65.98 & 64.46 & 6.25 & 10.28 & 2.10 & 54.43 & 29.95 & 13.11 & 4.05 \\
\hline & \pm 0.33 & \pm 0.61 & \pm 0.11 & \pm 0.10 & \pm 0.02 & \pm 0.87 & \pm 0.58 & \pm 0.26 & \pm 0.06 \\
\hline Max & 85.00 & 85.25 & 12.67 & 13.94 & 3.40 & 83.13 & 62.33 & 32.33 & 5.79 \\
\hline Min & 58.00 & 37.54 & 2.48 & 6.18 & 1.40 & 30.80 & 12.57 & 5.85 & 2.11 \\
\hline $\mathrm{CV} \%$ & 7.81 & 14.93 & 26.89 & 14.75 & 14.50 & 25.13 & 30.42 & 31.10 & 22.57 \\
\hline$\sigma^{2} \mathrm{~g}$ & 26.37 & 90.93 & 2.77 & 2.23 & 0.08 & 179.14 & 80.74 & 16.42 & 0.82 \\
\hline$\sigma^{2} p$ & 26.59 & 92.63 & 2.83 & 2.30 & 0.09 & 187.11 & 83.02 & 16.62 & 0.84 \\
\hline $\mathrm{H}$ & 99.16 & 98.16 & 97.89 & 97.16 & 90.26 & 95.74 & 97.25 & 98.80 & 98.52 \\
\hline$\Delta \mathrm{G}$ & 8.95 & 16.53 & 2.88 & 2.58 & 0.48 & 22.92 & 15.51 & 7.05 & 1.58 \\
\hline$\Delta \mathrm{G} / \mathrm{Mean}(\%)$ & 13.56 & 25.65 & 46.06 & 25.08 & 22.90 & 42.11 & 51.77 & 53.76 & 38.91 \\
\hline \multicolumn{10}{|l|}{ ICARDA 1} \\
\hline \multirow{2}{*}{ Means $\pm \mathrm{SE}$} & 66.33 & 70.67 & 4.85 & 11.02 & 2.50 & 53.52 & 33.83 & 12.10 & 4.68 \\
\hline & \pm 0.15 & \pm 0.39 & \pm 0.08 & \pm 0.07 & \pm 0.03 & \pm 1.08 & \pm 0.59 & \pm 0.16 & \pm 0.04 \\
\hline Max & 67.00 & 72.00 & 5.05 & 11.30 & 2.61 & 56.15 & 35.60 & 12.80 & 4.83 \\
\hline Min & 66.00 & 69.00 & 4.50 & 10.80 & 2.35 & 48.70 & 31.23 & 11.75 & 4.55 \\
\hline $\mathrm{CV} \%$ & 0.71 & 1.76 & 5.12 & 1.90 & 4.35 & 6.38 & 5.55 & 4.07 & 2.48 \\
\hline$\sigma^{2} p$ & 0.22 & 1.56 & 0.06 & 0.04 & 0.012 & 11.66 & 3.52 & 0.24 & 0.01 \\
\hline \multicolumn{10}{|l|}{ Gemmeza 7} \\
\hline \multirow{2}{*}{ Means \pm SE } & 64.67 & 69.80 & 5.38 & 10.80 & 2.02 & 49.05 & 28.95 & 10.85 & 4.12 \\
\hline & \pm 0.15 & \pm 0.43 & \pm 0.08 & \pm 0.09 & \pm 0.02 & \pm 0.65 & \pm 0.32 & \pm 0.13 & \pm 0.03 \\
\hline Max & 65.00 & 71.00 & 5.70 & 11.20 & 2.13 & 51.75 & 30.35 & 11.32 & 4.25 \\
\hline Min & 64.00 & 67.90 & 5.12 & 10.50 & 1.94 & 46.73 & 27.95 & 10.35 & 3.99 \\
\hline $\mathrm{CV} \%$ & 0.73 & 1.95 & 4.45 & 2.73 & 3.91 & 4.22 & 3.52 & 3.66 & 2.58 \\
\hline$\sigma 2 p$ & 0.22 & 1.85 & 0.06 & 0.09 & 0.01 & 4.28 & 1.04 & 0.16 & 0.011 \\
\hline
\end{tabular}

$\Delta \mathbf{G}=$ Expected genetic advance from selection $10 \%$ superior plants.

The range of the grain yield and its components in the $F_{2}$ populations fell outside the range of their respective parents, except for spike length in both populations. Number of spikes/plant for the parent ICARDA2 was higher than means in pop. 1, biological yield/plant (BYPP) for the two parents ICARDA2 and ICARDA5 were higher than pop. 1, but in pop. 2 only parent Gemmeza7 was higher than $\mathrm{F}_{2}$ plants and for grain yield/spike the parent ICARDA1 gave higher yield than pop. 2. In the same trend, for the two populations, plants were less than their parents in plant height and for days to heading, Gemmeza7 was earlier than $F_{2}$ plants pop. 2. This indicates transgressive segregation and/or heterozygosity. Means of the $F_{2}$ generation for the other traits rather grain yield/plant, respect to their respective parents differed in the two populations. This proves that the gene pool of the two populations were different in gene associations.

Heritability broad sense estimates in pop. 1 and pop. 2 were higher than $90 \%$ for all traits in this study, days to heading were 99.42 and $99.16 \%$, 
plant height was 98.68 and $98.16 \%$, number of spike/plant was 94.12 and $97.89 \%$, spike length was 98.29 and $97.16 \%$, grain yield/spike was 95.39 and $90.26 \%$, number of grain/spike was 94.91 and $95.74 \%$, biological yield/plant was 93.97 and $97.25 \%$, grain yield/plant was 97.27 and $98.80 \%$ and 100-grain weight was 98.14 and $98.52 \%$. High estimates of broad sense heritability coupled with high or moderate $\sigma^{2} \mathrm{p}$ gave high estimates of expected genetic advance from selection of $10 \%$ superior plants for days to heading, plant height, number of grains per spike and biological yield per plant. The expected genetic advance ranged from 14.71 and $8.95 \%$ for DH to 18.63 and $16.53 \%$ for PH, 2.32 and $2.88 \%$ for NSPP, 2.77 and $2.58 \%$ for SL, 14.36 and $22.92 \%$ for NGPS, 13.25 and $15.51 \%$ for BYPP and 1.19 and $1.53 \%$ for $100-\mathrm{GW}$ in pop. 1 and pop. 2 , respectively.

The correlation coefficient among all traits in the $F_{2}$ plants (pop. 1 and pop. 2) are presented in table (6). Simple correlation coefficients for both populations were small, and highly and/or significant. That is mainly due to the large number of plants in the base populations. Grain yield/plant showed positive and significant correlation $(p \leq 0.05 \leq 0.01)$ between all studied traits for the two populations, except days to heading (DH), which was negative and significant in pop. 1 and only negative in pop. 2. Simple correlation coefficients was negative and significant between DH and all studied trait in pop. 1 and only between NGPS in pop. 2, the positive and significant $(p \leq 0.05 \leq 0.01)$ between all traits in the two populations, except NGPS between NSPP and SL in pop. 1 and NGPS between BYPP and GYPP and between NSPP and 100-GW in pop. 2. The results of correlations indicated that different genes were controlling for both populations. These results are in agreement with those reported by El Ameen et al. (2013) and Al-Naggar and Shehab El-Deen (2012).

Table (6). Simple correlation coefficients among the traits in the $F_{2}$ generation in pop. 1 (above diagonal) and in pop. 2 (below diagonal).

\begin{tabular}{|c|c|c|c|c|c|c|c|c|c|}
\hline Traits & DH & $\mathbf{P H}$ & NSPP & SL & GYPS & NGPS & BYPP & GYPP & 100-GW \\
\hline $\mathrm{DH}$ & - & $-0.294 * *$ & $-0.163^{*}$ & $-0.337 * *$ & $-0.388^{* *}$ & $-0.196^{* *}$ & -0.053 & $-0.101 * *$ & $-0.255^{* *}$ \\
\hline $\mathrm{PH}$ & 0.124 & - & $0.336 * *$ & $0.765^{* *}$ & $0.591 * *$ & 0.053 & $0.384 * *$ & $0.351 * *$ & $0.574 * *$ \\
\hline NSPP & 0.010 & $0.214 * *$ & 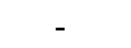 & $0.340 * *$ & $0.280 * *$ & 0.003 & $0.841 * *$ & $0.898 * *$ & $0.301 * *$ \\
\hline SL & $0.179 * *$ & $0.864 * *$ & $0.220 * *$ & - & $0.673 * *$ & -0.036 & $0.403 * *$ & $0.361 * *$ & $0.752 * *$ \\
\hline GYPS & -0.119 & $0.264 * *$ & -0.036 & $0.224 * *$ & - & $0.477 * *$ & $0.571 * *$ & $0.521 * *$ & $0.654 * *$ \\
\hline NGPS & $-0.390 * *$ & $-0.474 * *$ & -0.088 & $-0.610 * *$ & $0.385^{* *}$ & - & $0.221 * *$ & $0.277 * *$ & $-0.342 * *$ \\
\hline BYPP & 0.052 & $0.395 * *$ & $0.853 * *$ & $0.422 * *$ & $0.318^{* *}$ & -0.099 & - & $0.951 * *$ & $0.411 * *$ \\
\hline GYPP & -0.043 & $0.287 * *$ & $0.890 * *$ & $0.275 * *$ & $0.409 * *$ & 0.112 & $0.921 * *$ & . & $0.314 * *$ \\
\hline 100-GW & $0.407 * *$ & $0.655 * *$ & 0.049 & $0.786 * *$ & $0.147 *$ & $-0.836 * *$ & $0.265^{* *}$ & 0.087 & - \\
\hline
\end{tabular}

Egyptian J. Desert Res., 69, Special Issue, 1-18 (2019) 


\section{Pedigree Selection for GYPS, NGPS, 100-GW and (GYPP), Variability and Heritability Estimates}

Combined analysis of variance under two water stresses of the RCBD design for the studied 27 entries of wheat $(25$ selected families +2 parents + bulk sample) is presented in tables ( 7 and 8$)$. Mean squares due to irrigation were significant $(p \leq 0.01)$ for all traits study in both populations, except for NGPS in the two populations.

Table (7). Mean squares, heritability in broad sense (H), genotypic (GCV\%) and phenotypic (PCV\%) coefficients of variability of the selected families for grain yield per plant (GYPP) in the $F_{3}$ generation in both populations, season 2016/2017 under normal and drought irrigations.

\begin{tabular}{|c|c|c|c|c|c|c|c|c|c|c|c|}
\hline \multirow{13}{*}{ 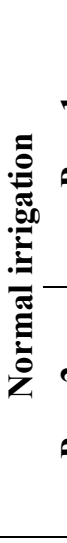 } & S.O.V. & df & DH & PH & NSPP & SL & GYPS & NGPS & BYPP & GYPP & 100-GW \\
\hline & Reps & 2 & 0.81 & 12.42 & $0.760^{*}$ & 0.438 & $0.405^{* *}$ & $190.57 * *$ & $291.09^{* *}$ & $37.03 * *$ & $0.075^{*}$ \\
\hline & - Entries & 27 & $33.23^{* *}$ & $136.15^{* *}$ & $3.626^{* *}$ & $4.844^{* *}$ & $0.288^{* *}$ & $59.00^{* *}$ & $227.24 * *$ & $42.35^{* *}$ & $0.458^{* *}$ \\
\hline & $\dot{\mathrm{\theta}}$ Error & 54 & 1.31 & 11.23 & 0.237 & 0.195 & 0.058 & 24.04 & 34.12 & 3.74 & 0.017 \\
\hline & GCV\% & & 5.02 & 8.91 & 19.22 & 11.77 & 10.00 & 5.87 & 22.60 & 25.90 & 8.00 \\
\hline & PCV\% & & 5.25 & 9.98 & 21.12 & 12.45 & 14.10 & 11.18 & 27.85 & 29.37 & 8.49 \\
\hline & $\mathrm{H}$ & & 91.44 & 79.62 & 82.86 & 89.39 & 50.30 & 27.55 & 65.87 & 77.79 & 88.71 \\
\hline & Reps & 2 & $21.94 * *$ & $82.88^{* *}$ & 0.046 & 0.396 & $0.113^{*}$ & $55.90 *$ & $76.78^{*}$ & 3.21 & 0.005 \\
\hline & Entries & 27 & $188.18^{* *}$ & $150.03 * *$ & $7.307^{* *}$ & $2.526^{* *}$ & $0.283^{* *}$ & $108.39 * *$ & $581.27 * *$ & $96.51^{* *}$ & $0.832 * *$ \\
\hline & Error & 54 & 1.45 & 7.11 & 0.215 & 0.141 & 0.032 & 15.03 & 22.37 & 2.20 & 0.021 \\
\hline & GCV\% & & 10.81 & 9.26 & 24.27 & 7.68 & 5.78 & 8.65 & 25.29 & 27.43 & 9.86 \\
\hline & PCV\% & & 10.92 & 9.93 & 25.40 & 8.35 & 8.50 & 10.95 & 27.08 & 28.59 & 10.32 \\
\hline & $\mathrm{H}$ & & 97.85 & 86.84 & 91.36 & 84.50 & 46.13 & 62.42 & 87.17 & 92.02 & 91.27 \\
\hline \multirow{12}{*}{ 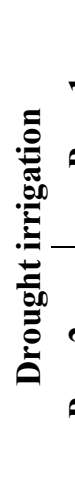 } & Reps & 2 & 1.87 & 3.76 & 0.035 & 0.463 & $0.090 *$ & $48.23 *$ & $30.38^{*}$ & $4.10^{*}$ & 0.019 \\
\hline & Entries & 27 & $41.22^{* *}$ & $141.58 * *$ & $4.307^{* *}$ & $4.934^{* *}$ & $0.165^{* *}$ & $72.39^{* *}$ & $103.10 * *$ & $28.23 * *$ & $0.318^{* *}$ \\
\hline & Error & 54 & 1.29 & 8.42 & 0.199 & 0.187 & 0.023 & 15.08 & 8.29 & 1.17 & 0.023 \\
\hline & GCV\% & & 6.45 & 10.25 & 23.70 & 13.88 & 9.14 & 8.48 & 22.30 & 29.90 & 7.41 \\
\hline & PCV\% & & 6.62 & 11.13 & 25.04 & 14.62 & 12.28 & 11.82 & 25.15 & 31.96 & 8.30 \\
\hline & $\mathrm{H}$ & & 94.92 & 84.79 & 89.56 & 90.15 & 55.33 & 51.38 & 78.60 & 87.53 & 79.79 \\
\hline & Reps & 2 & $7.43 *$ & $27.70^{* *}$ & 0.117 & $0.512 * *$ & $0.083^{*}$ & 44.22 & 28.13 & 2.40 & 0.001 \\
\hline & Entries & 27 & $99.74 * *$ & $78.20^{* *}$ & $6.585^{* *}$ & $2.725^{* *}$ & $0.089^{* *}$ & $98.01^{* *}$ & $288.77^{* *}$ & $40.21^{* *}$ & $0.427 * *$ \\
\hline & $\therefore$ Error & 54 & 1.95 & 5.32 & 0.223 & 0.089 & 0.024 & 15.83 & 9.20 & 0.79 & 0.036 \\
\hline & GCV\% & & 8.79 & 7.48 & 23.01 & 9.49 & 5.30 & 8.94 & 25.39 & 25.89 & 9.87 \\
\hline & PCV\% & & 9.01 & 8.25 & 24.17 & 9.93 & 8.94 & 11.39 & 26.72 & 26.83 & 11.19 \\
\hline & $\mathrm{H}$ & & 95.04 & 82.28 & 90.67 & 91.27 & 35.13 & 61.71 & 90.26 & 93.12 & 77.87 \\
\hline
\end{tabular}


Table (8). Mean squares of the selected families for grain yield per plant (GYPP)in the $F_{3}$ generation in both populations over two irrigation levels, season 2016/2017.

\begin{tabular}{|c|c|c|c|c|c|c|c|c|c|c|}
\hline S.O.V & df & DH & PH & NSPP & SL & GYPS & NGPS & BYPP & GYPP & 100-GW \\
\hline Irrigation & 1 & $1625.04 * *$ & $2679.81 * *$ & $15.232 * *$ & $114.838 * *$ & $11.864 * *$ & 804.26 & $5071.99 * *$ & 742.90 ** & $19.948^{* *}$ \\
\hline I I (Rep.) & 4 & 1.34 & 8.09 & 0.397 & 0.451 & 0.248 & 119.40 & 160.74 & 20.56 & 0.047 \\
\hline 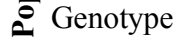 & 27 & $69.57 * *$ & $271.04 * *$ & $7.772 * *$ & $9.649 * *$ & $0.430 * *$ & $126.25^{* *}$ & $311.31 * *$ & $69.44 * *$ & $0.698 * *$ \\
\hline$I^{*} \mathrm{G}$ & 27 & $4.88 * *$ & 6.69 & 0.162 & 0.129 & 0.023 & 5.13 & 19.03 & 1.14 & $0.078 * *$ \\
\hline Error & 108 & 1.30 & 9.83 & 0.218 & 0.191 & 0.041 & 19.56 & 21.20 & 2.46 & 0.020 \\
\hline Irrigation & 1 & $3198.15^{* *}$ & $4256.89 * *$ & $4.445^{* *}$ & $111.594^{* *}$ & $28.776 * *$ & 383.22 & $7713.34 * *$ & $1513.22 * *$ & $60.648^{* *}$ \\
\hline $\boldsymbol{N}$ I (Rep.) & 4 & 14.68 & 55.29 & 0.082 & 0.454 & 0.098 & 50.06 & 52.45 & 2.80 & 0.003 \\
\hline 气 Genotype & 27 & $274.83 * *$ & $186.34 * *$ & $13.784 * *$ & $4.876 * *$ & $0.329 * *$ & $200.56 * *$ & $828.84 * *$ & $129.87 * *$ & $1.132 * *$ \\
\hline A $I^{*} \mathrm{G}$ & 27 & $13.09 * *$ & $41.89 * *$ & 0.108 & $0.376^{* *}$ & 0.043 & 5.85 & $41.20 * *$ & $6.85^{* *}$ & $0.127 * *$ \\
\hline Error & 108 & 1.70 & 6.22 & 0.219 & 0.115 & 0.028 & 15.43 & 15.78 & 1.49 & 0.028 \\
\hline
\end{tabular}

After the first cycle of pedigree selection rapidly depleted the variability in the selection criterion (grain yield/plant (GYPP). Its PCV were high (more than $10 \%$ ), which were $29.37 \%$ in pop. 1 and $28.59 \%$ in pop. 2 under normal irrigation, while were 31.96 and $26.83 \%$ in pop. 1 and pop. 2 under drought stress, respectively, in $\mathrm{F}_{3}$ generation. The GCV also was high (more than 10\%), 25.90 in pop. 1 and 27.43 in pop. 2 under normal irrigation and 29.90 and $25.89 \%$ for pop. 1 and pop. 2 under drought stress, respectively. Therefore, further cycle of selection for GYPP will be fruitful under the two water irrigation and in both populations and selection for this trait should be practiced in this cycle of $\mathrm{F}_{3}$ segregating generations. Selection under direct (normal irrigation) and indirect (drought stress) selection to GYPP were the same for theses entries. The PCV and GCV for most other traits in pop. 1 under normal irrigation and drought stress were high (more than 10\%), except for $\mathrm{DH}$ and $100-\mathrm{GW}$ under both water stresses for phenotypic and genotypic coefficient variances and for $\mathrm{PH}$ under normal irrigation. GCV\% was less than $10 \%$ under drought irrigation for GYPS and NGPS for both irrigation regimes. In the same trend, the phenotypic and genotypic coefficients of variability in pop. 2 were high (more than 10\%) for NSPP and BYPP under both water irrigations. However, it recorded less than $10 \%$ for PH, SL and GYPS under two the water stresses and for DH under drought stress. GCV\% was less than $10 \%$ for NGPS and $100-\mathrm{GW}$ under normal irrigation and drought stress, and resulted high estimates of heritability for all studied traits, except for NGPS in pop. 1 under normal irrigation (27.55\%) and for GYPS in pop. 2 under drought stress (35.13\%). The other cause of very high estimates of heritability was the large mean squares of families compared to small error variance. This could be ascribed to evaluate the selected families at Toshka region for one season. These results are in general agreement with those reported by Memon et al. (2018) and Patel et al. (2019). 


\section{Means and Direct Observed Selection Gain}

Means of the nine studied traits under the two irrigation water practices (normal irrigation and drought stress) for 25 families and their parents for two populations, which selected in the $F_{3}$ generation to GYPP is presented in table (9). In general, The average observed selection gain for GYPP was significant $(p \leq 0.05 \leq 0.01)$ and higher than bulk sample under normal irrigation and drought stress, respectively. GYPP of the family number 16 was the best and highly significant $(p \leq 0.01)$ than average, better parent and unselected bulk sample under both water treatments. Families number 9 and 14 under water stress recorded higher values than means, bulk and these parents. Family number 10 was only significant $(p \leq 0.05)$ under normal irrigation, while families number $1,4,5$ and 6 were significant under both irrigation treatments in pop. 2. The average of grain yield/plant (GYPP) for observed selection gain in pop. 2 was significant $(p \leq 0.05 \leq 0.01)$ and higher than bulk sample under normal irrigation and drought stress, that must be the best selected families with high and significant $(p \leq 0.05 \leq 0.01)$ GYPP.

For DH trait, family number 22 in pop. 1 showed the lowest number of days of the lower parent under both water irrigations. The families number 4 and 11 under normal irrigation and water stress give the highest plant height in Pop. 1, and family No 25 recorded the high plant height under water stress in Pop. 2. Regarding to NSPP, the families No. 15 in Pop. 1, families No. 5 and 16 under normal and drought stress in Pop. 2, respectively. While the two families No. 11 and 7 recorded the best values for SL in Pop. 1 and Pop. 2, respectively. On the same trend, the families No. 17 and 7 recorded the highest values in GYPS in Pop. 1 and Pop. 2 under normal irrigation. For NGPS the family No. 16 given the best number of grains/spike under both water irrigations in Pop. 1 and family No. 24 in Pop. 2 for the same trait. The highest value for BYPP were recorded by families No. 15 and 16 under the two-water irrigations in Pop. 1 and Pop. 2, respectively. While for 100-GW the family No. 3 given the best value under both water irrigations in Pop. 1, however, in Pop. 2 the families No. 15 and 1 under normal irrigation and water stress, respectively. This result concluded that selection for these traits in these families might be useful in direct environment (under water stress) and indirect environment (normal irrigation). 
Table (9). Mean performance all studied characters of the selected families in the $\mathrm{F}_{3}$ generation in two populations for GYPP under normal and drought stress, season 2016/2017.

\begin{tabular}{|c|c|c|c|c|c|c|c|c|}
\hline \multirow{3}{*}{ Family } & Pop. 1 & Pop. 2 & Pop. 1 & Pop. 2 & Pop. 1 & Pop. 2 & Pop. 1 & Pop. 2 \\
\hline & \multicolumn{2}{|c|}{ Normal irrigation } & \multicolumn{2}{|c|}{ Drought stress } & \multicolumn{2}{|c|}{ Normal irrigation } & \multicolumn{2}{|c|}{ Drought stress } \\
\hline & \multicolumn{4}{|c|}{ DH } & \multicolumn{4}{|c|}{ PH } \\
\hline 1 & 64.67 & 70.00 & 60.67 & 61.67 & 72.78 & 74.71 & 69.75 & 67.92 \\
\hline 2 & 67.67 & 66.67 & 61.67 & 62.00 & 77.00 & 68.20 & 70.00 & 62.00 \\
\hline 3 & 68.33 & 69.33 & 62.33 & 63.00 & 78.19 & 75.44 & 71.08 & 69.83 \\
\hline 4 & 70.33 & 71.00 & 63.33 & 62.00 & 88.83 & 73.79 & 81.00 & 67.08 \\
\hline 5 & 70.00 & 70.67 & 62.67 & 63.00 & 88.73 & 73.70 & 80.67 & 69.42 \\
\hline 6 & 65.00 & 72.00 & 61.67 & 63.67 & 68.93 & 85.25 & 62.67 & 77.50 \\
\hline 7 & 65.33 & 69.00 & 60.00 & 61.00 & 71.87 & 86.72 & 65.33 & 77.50 \\
\hline 8 & 67.00 & 68.00 & 62.00 & 61.00 & 87.27 & 72.05 & 79.33 & 65.50 \\
\hline 9 & 65.33 & 67.00 & 62.00 & 60.33 & 72.42 & 67.83 & 65.83 & 62.92 \\
\hline 10 & 68.67 & 71.33 & 62.00 & 63.67 & 73.79 & 77.73 & 67.08 & 72.00 \\
\hline 11 & 70.33 & 69.67 & 63.00 & 61.67 & 92.22 & 72.05 & 83.83 & 65.50 \\
\hline 12 & 66.33 & 68.67 & 62.00 & 61.33 & 73.98 & 72.88 & 66.75 & 66.25 \\
\hline 13 & 62.67 & 67.67 & 60.33 & 61.33 & 64.08 & 71.50 & 58.25 & 65.00 \\
\hline 14 & 68.33 & 67.00 & 62.33 & 61.00 & 88.18 & 62.24 & 80.17 & 56.58 \\
\hline 15 & 67.00 & 68.67 & 62.00 & 61.33 & 81.40 & 67.47 & 74.00 & 61.33 \\
\hline 16 & 67.00 & 72.33 & 61.00 & 63.67 & 79.02 & 81.13 & 71.83 & 73.75 \\
\hline 17 & 67.00 & 78.33 & 61.67 & 71.67 & 74.80 & 80.33 & 68.00 & 71.33 \\
\hline 18 & 64.00 & 80.33 & 57.33 & 70.33 & 73.80 & 82.33 & 65.77 & 66.67 \\
\hline 19 & 64.00 & 81.33 & 57.00 & 74.67 & 75.83 & 83.33 & 62.33 & 64.00 \\
\hline 20 & 62.33 & 75.67 & 54.67 & 66.33 & 73.03 & 86.67 & 65.70 & 68.67 \\
\hline 21 & 60.33 & 86.33 & 56.00 & 77.67 & 71.60 & 77.00 & 60.40 & 61.00 \\
\hline 22 & 58.67 & 90.67 & 50.67 & 76.00 & 69.67 & 73.00 & 57.73 & 60.67 \\
\hline 23 & 60.00 & 83.67 & 51.33 & 68.33 & 72.63 & 84.33 & 65.47 & 63.00 \\
\hline 24 & 61.00 & 91.00 & 54.00 & 77.00 & 74.83 & 86.33 & 63.63 & 72.00 \\
\hline 25 & 62.00 & 90.00 & 53.67 & 73.33 & 76.13 & 90.33 & 67.17 & 68.33 \\
\hline Average & 65.33 & 74.65 & 59.41 & 65.88 & 76.84 & 77.05 & 68.95 & 67.03 \\
\hline P1 & 65.33 & 68.33 & 56.67 & 60.33 & 78.00 & 71.67 & 67.27 & 63.34 \\
\hline $\mathrm{P} 2$ & 68.50 & 65.67 & 59.67 & 58.67 & 75.03 & 70.50 & 68.00 & 60.53 \\
\hline Bulk & 70.33 & 77.00 & 61.67 & 67.00 & 77.67 & 77.33 & 69.00 & 64.33 \\
\hline $\begin{array}{c}\text { RLSD } \\
0.05 \\
\end{array}$ & 1.67 & 1.72 & 1.66 & 2.04 & 5.06 & 3.90 & 4.24 & 3.49 \\
\hline \multirow[t]{2}{*}{$\begin{array}{c}\text { RLSD } \\
0.01 \\
\end{array}$} & 2.18 & 2.25 & 2.17 & 2.67 & 6.65 & 5.10 & 5.54 & 4.58 \\
\hline & \multicolumn{4}{|c|}{ NSPP } & \multicolumn{4}{|c|}{ SL } \\
\hline 1 & 6.82 & 9.07 & 6.26 & 8.23 & 12.31 & 11.40 & 10.71 & 9.92 \\
\hline 2 & 7.05 & 6.12 & 6.48 & 5.67 & 10.83 & 11.98 & 9.42 & 10.42 \\
\hline 3 & 6.83 & 6.49 & 6.65 & 6.33 & 13.27 & 11.07 & 11.54 & 9.63 \\
\hline 4 & 6.06 & 8.90 & 5.64 & 8.57 & 12.36 & 11.93 & 10.75 & 10.38 \\
\hline 5 & 5.89 & 9.30 & 5.80 & 8.63 & 10.97 & 12.31 & 9.54 & 10.63 \\
\hline 6 & 6.21 & 8.20 & 5.92 & 7.75 & 11.64 & 13.18 & 10.13 & 11.46 \\
\hline 7 & 6.02 & 5.73 & 5.80 & 5.55 & 10.83 & 13.75 & 9.42 & 11.96 \\
\hline 8 & 6.57 & 5.36 & 5.99 & 5.12 & 13.13 & 12.70 & 11.42 & 11.04 \\
\hline
\end{tabular}

Egyptian J. Desert Res., 69, Special Issue, 1-18 (2019) 
Table (9). Cont.

\begin{tabular}{|c|c|c|c|c|c|c|c|c|}
\hline 9 & 7.05 & 7.47 & 6.21 & 7.25 & 11.79 & 11.55 & 10.25 & 10.04 \\
\hline 10 & 6.47 & 7.54 & 5.53 & 7.21 & 11.12 & 12.84 & 9.67 & 11.17 \\
\hline 11 & 6.02 & 7.11 & 5.64 & 6.73 & 13.46 & 11.16 & 11.71 & 9.71 \\
\hline 12 & 5.13 & 5.37 & 4.95 & 5.27 & 10.59 & 12.41 & 9.21 & 10.79 \\
\hline 13 & 5.92 & 6.37 & 5.64 & 6.40 & 11.64 & 10.73 & 10.13 & 9.33 \\
\hline 14 & 7.05 & 8.35 & 6.53 & 7.57 & 13.27 & 12.12 & 11.54 & 10.54 \\
\hline 15 & 8.01 & 6.27 & 7.24 & 6.14 & 10.88 & 12.51 & 9.46 & 10.88 \\
\hline 16 & 7.06 & 9.03 & 6.80 & 8.78 & 12.17 & 12.60 & 10.58 & 10.96 \\
\hline 17 & 5.20 & 5.23 & 4.80 & 5.10 & 12.17 & 12.67 & 10.58 & 10.95 \\
\hline 18 & 4.74 & 4.67 & 4.12 & 4.53 & 10.32 & 12.80 & 8.43 & 11.17 \\
\hline 19 & 4.71 & 6.03 & 3.96 & 5.90 & 9.92 & 12.50 & 7.50 & 9.95 \\
\hline 20 & 4.91 & 4.58 & 4.00 & 4.50 & 9.53 & 11.00 & 7.80 & 9.18 \\
\hline 21 & 4.21 & 4.48 & 3.40 & 4.45 & 10.44 & 10.27 & 7.97 & 9.00 \\
\hline 22 & 3.81 & 4.90 & 3.11 & 4.70 & 9.17 & 9.98 & 7.87 & 8.08 \\
\hline 23 & 4.50 & 4.83 & 3.51 & 4.68 & 9.58 & 10.90 & 8.07 & 8.62 \\
\hline 24 & 4.31 & 4.92 & 3.53 & 4.66 & 8.87 & 11.23 & 7.43 & 9.13 \\
\hline 25 & 4.14 & 5.27 & 3.24 & 4.95 & 9.80 & 11.83 & 8.47 & 9.02 \\
\hline Average & 5.79 & 6.46 & 5.23 & 6.19 & 11.20 & 11.90 & 9.58 & 10.16 \\
\hline $\mathrm{P} 1$ & 6.40 & 5.17 & 4.83 & 4.37 & 11.23 & 11.25 & 9.17 & 11.02 \\
\hline $\mathrm{P} 2$ & 5.10 & 5.07 & 4.67 & 4.03 & 11.17 & 11.23 & 9.21 & 10.80 \\
\hline Bulk & 5.97 & 5.13 & 5.05 & 4.77 & 11.67 & 11.00 & 9.90 & 9.53 \\
\hline $\begin{array}{c}\text { RLSD } \\
0.05 \\
\end{array}$ & 0.73 & 0.68 & 0.65 & 0.69 & 0.65 & 0.55 & 0.63 & 0.43 \\
\hline $\begin{array}{c}\text { RLSD } \\
0.01 \\
\end{array}$ & 0.97 & 0.89 & 0.85 & 0.90 & 0.84 & 0.72 & 0.83 & 0.57 \\
\hline & \multicolumn{4}{|c|}{ GYPS } & \multicolumn{4}{|c|}{ NGPS } \\
\hline 1 & 2.29 & 3.10 & 1.90 & 2.28 & 47.40 & 58.88 & 43.71 & 51.98 \\
\hline 2 & 2.31 & 2.70 & 1.79 & 1.95 & 48.57 & 52.17 & 42.80 & 48.52 \\
\hline 3 & 2.80 & 2.77 & 2.09 & 2.04 & 52.26 & 54.20 & 42.97 & 47.88 \\
\hline 4 & 2.64 & 3.09 & 2.13 & 2.15 & 53.75 & 60.57 & 48.80 & 54.75 \\
\hline 5 & 2.38 & 3.09 & 1.78 & 2.04 & 47.13 & 57.24 & 42.67 & 52.25 \\
\hline 6 & 2.48 & 3.32 & 1.91 & 2.41 & 48.86 & 60.85 & 44.86 & 58.04 \\
\hline 7 & 2.39 & 3.24 & 1.82 & 2.28 & 46.31 & 57.68 & 41.82 & 56.58 \\
\hline 8 & 2.33 & 3.10 & 1.88 & 2.24 & 51.44 & 58.19 & 47.13 & 56.71 \\
\hline 9 & 2.45 & 3.23 & 2.03 & 2.38 & 55.16 & 59.78 & 49.75 & 56.00 \\
\hline 10 & 2.75 & 3.05 & 2.07 & 2.16 & 58.32 & 58.80 & 51.87 & 55.80 \\
\hline 11 & 2.73 & 3.16 & 2.18 & 2.10 & 54.53 & 61.10 & 52.23 & 58.23 \\
\hline 12 & 2.77 & 2.99 & 2.04 & 2.09 & 56.36 & 54.90 & 53.99 & 52.43 \\
\hline 13 & 2.68 & 2.90 & 2.02 & 2.10 & 52.92 & 55.63 & 49.58 & 53.63 \\
\hline 14 & 2.55 & 2.81 & 2.02 & 2.04 & 54.48 & 55.47 & 53.23 & 53.87 \\
\hline 15 & 2.69 & 3.22 & 2.14 & 2.05 & 54.39 & 56.70 & 52.59 & 54.96 \\
\hline 16 & 2.82 & 3.09 & 2.12 & 2.17 & 62.13 & 62.53 & 56.14 & 61.04 \\
\hline 17 & 2.87 & 2.59 & 2.12 & 1.87 & 57.87 & 59.36 & 55.94 & 58.63 \\
\hline 18 & 2.16 & 2.91 & 1.65 & 2.03 & 49.96 & 67.32 & 45.46 & 60.22 \\
\hline 19 & 2.11 & 2.65 & 1.60 & 1.81 & 44.52 & 53.77 & 41.12 & 52.79 \\
\hline 20 & 1.94 & 2.96 & 1.53 & 2.10 & 47.08 & 60.50 & 40.80 & 57.80 \\
\hline 21 & 2.08 & 3.16 & 1.71 & 2.23 & 51.26 & 63.70 & 46.41 & 60.45 \\
\hline
\end{tabular}

Egyptian J. Desert Res., 69, Special Issue, 1-18 (2019) 
Table (9). Cont.

\begin{tabular}{|c|c|c|c|c|c|c|c|c|}
\hline 22 & 2.15 & 2.89 & 1.81 & 2.11 & 50.00 & 69.73 & 46.71 & 67.61 \\
\hline 23 & 2.00 & 2.76 & 1.55 & 2.04 & 50.84 & 66.14 & 46.55 & 63.09 \\
\hline 24 & 2.21 & 3.17 & 1.75 & 2.25 & 52.81 & 75.30 & 46.44 & 70.62 \\
\hline 25 & 2.35 & 2.78 & 1.94 & 2.03 & 53.52 & 71.03 & 49.89 & 67.34 \\
\hline Average & 2.44 & 2.99 & 1.90 & 2.12 & 52.07 & 60.46 & 47.74 & 57.25 \\
\hline P1 & 1.79 & 2.45 & 1.48 & 1.85 & 43.62 & 51.60 & 41.29 & 49.27 \\
\hline $\mathrm{P} 2$ & 2.35 & 2.25 & 1.74 & 1.78 & 50.13 & 53.42 & 46.00 & 49.78 \\
\hline Bulk & 1.87 & 2.05 & 1.26 & 1.71 & 45.30 & 51.47 & 37.64 & 53.15 \\
\hline $\begin{array}{c}\text { RLSD } \\
0.05 \\
\end{array}$ & 0.40 & 0.27 & 0.24 & 0.26 & 9.41 & 6.11 & 6.50 & 6.27 \\
\hline \multirow[t]{2}{*}{$\begin{array}{c}\text { RLSD } \\
0.01 \\
\end{array}$} & 0.50 & 0.35 & 0.32 & 0.34 & 12.89 & 8.04 & 8.05 & 8.25 \\
\hline & \multicolumn{4}{|c|}{ BYPP } & \multicolumn{4}{|c|}{ GYPP } \\
\hline 1 & 39.67 & 73.52 & 29.87 & 50.59 & 15.61 & 28.16 & 11.88 & 18.76 \\
\hline 2 & 41.57 & 44.27 & 29.23 & 29.98 & 16.37 & 16.51 & 11.63 & 11.01 \\
\hline 3 & 46.47 & 47.47 & 35.63 & 37.11 & 19.15 & 18.01 & 13.87 & 12.93 \\
\hline 4 & 41.50 & 69.07 & 28.53 & 51.41 & 16.04 & 27.56 & 11.97 & 18.41 \\
\hline 5 & 36.57 & 72.25 & 24.37 & 47.61 & 13.97 & 28.69 & 10.22 & 17.64 \\
\hline 6 & 40.13 & 66.83 & 27.50 & 51.50 & 15.53 & 27.19 & 11.34 & 18.53 \\
\hline 7 & 37.59 & 48.35 & 25.56 & 35.10 & 14.62 & 18.58 & 10.63 & 12.68 \\
\hline 8 & 36.87 & 41.35 & 27.59 & 31.89 & 15.39 & 16.60 & 11.28 & 11.45 \\
\hline 9 & 43.80 & 59.10 & 28.82 & 47.39 & 17.18 & 24.02 & 12.53 & 17.19 \\
\hline 10 & 46.67 & 57.37 & 26.89 & 43.01 & 17.81 & 22.97 & 11.44 & 15.56 \\
\hline 11 & 41.20 & 57.32 & 28.60 & 38.85 & 16.41 & 22.35 & 12.27 & 14.12 \\
\hline 12 & 34.34 & 43.10 & 23.78 & 30.29 & 14.14 & 15.92 & 10.12 & 10.96 \\
\hline 13 & 39.84 & 51.33 & 27.67 & 37.29 & 15.93 & 18.40 & 11.39 & 13.37 \\
\hline 14 & 46.13 & 60.02 & 32.29 & 43.52 & 17.94 & 23.46 & 13.12 & 15.46 \\
\hline 15 & 53.73 & 52.65 & 37.34 & 35.85 & 21.52 & 20.17 & 15.56 & 12.57 \\
\hline 16 & 49.33 & 76.53 & 34.59 & 51.51 & 19.93 & 27.98 & 14.47 & 18.99 \\
\hline 17 & 39.87 & 37.62 & 23.97 & 25.09 & 14.90 & 13.53 & 10.19 & 9.53 \\
\hline 18 & 28.12 & 35.98 & 20.67 & 25.64 & 10.17 & 13.53 & 6.79 & 9.19 \\
\hline 19 & 27.35 & 42.57 & 19.70 & 28.62 & 9.91 & 15.98 & 6.32 & 10.60 \\
\hline 20 & 28.47 & 36.02 & 20.53 & 25.71 & 9.51 & 13.58 & 6.13 & 9.40 \\
\hline 21 & 25.40 & 37.00 & 19.13 & 26.86 & 8.73 & 14.18 & 5.82 & 9.90 \\
\hline 22 & 23.50 & 37.93 & 16.60 & 27.64 & 8.18 & 14.15 & 5.63 & 9.90 \\
\hline 23 & 22.60 & 34.73 & 17.23 & 25.93 & 9.01 & 13.34 & 5.46 & 9.57 \\
\hline 24 & 23.47 & 41.78 & 18.00 & 30.16 & 9.54 & 15.56 & 6.19 & 10.48 \\
\hline 25 & 24.83 & 42.16 & 16.90 & 29.50 & 9.73 & 14.62 & 6.26 & 10.01 \\
\hline Average & 36.76 & 50.65 & 25.64 & 36.32 & 14.29 & 19.40 & 10.10 & 13.13 \\
\hline P1 & 29.97 & 34.58 & 20.77 & 21.95 & 11.43 & 12.65 & 7.06 & 8.02 \\
\hline $\mathrm{P} 2$ & 31.07 & 29.43 & 22.63 & 19.69 & 11.99 & 11.39 & 8.09 & 7.15 \\
\hline Bulk & 30.80 & 27.80 & 18.77 & 28.97 & 11.10 & 10.48 & 6.33 & 8.10 \\
\hline $\begin{array}{c}\text { RLSD } \\
0.05 \\
\end{array}$ & 9.20 & 6.91 & 4.35 & 4.43 & 2.92 & 2.17 & 1.58 & 1.30 \\
\hline $\begin{array}{c}\text { RLSD } \\
0.01 \\
\end{array}$ & 12.11 & 9.04 & 5.71 & 5.79 & 3.84 & 2.83 & 2.07 & 1.70 \\
\hline
\end{tabular}

Egyptian J. Desert Res., 69, Special Issue, 1-18 (2019) 
Table (9). Cont.

\begin{tabular}{|c|c|c|c|c|}
\hline \multicolumn{5}{|c|}{ 100-GW } \\
\hline 1 & 4.83 & 5.28 & 4.34 & 4.39 \\
\hline 2 & 4.76 & 5.16 & 4.19 & 4.01 \\
\hline 3 & 5.38 & 5.12 & 4.85 & 4.28 \\
\hline 4 & 4.94 & 5.11 & 4.37 & 3.94 \\
\hline 5 & 5.04 & 5.40 & 4.16 & 3.90 \\
\hline 6 & 5.07 & 5.46 & 4.25 & 4.15 \\
\hline 7 & 5.15 & 5.62 & 4.36 & 4.03 \\
\hline 8 & 4.54 & 5.32 & 3.99 & 3.95 \\
\hline 9 & 4.45 & 5.39 & 4.08 & 4.25 \\
\hline 10 & 4.72 & 5.20 & 3.99 & 3.87 \\
\hline 11 & 5.01 & 5.16 & 4.18 & 3.62 \\
\hline 12 & 4.90 & 5.43 & 3.79 & 3.96 \\
\hline 13 & 5.07 & 5.21 & 4.07 & 3.91 \\
\hline 14 & 4.68 & 5.07 & 3.79 & 3.79 \\
\hline 15 & 4.94 & 5.68 & 4.08 & 3.73 \\
\hline 16 & 4.54 & 4.95 & 3.79 & 3.56 \\
\hline 17 & 4.96 & 4.38 & 3.78 & 3.21 \\
\hline 18 & 4.31 & 4.32 & 3.63 & 3.38 \\
\hline 19 & 4.73 & 4.94 & 3.89 & 3.42 \\
\hline 20 & 4.11 & 4.89 & 3.76 & 3.63 \\
\hline 21 & 4.05 & 4.97 & 3.69 & 3.69 \\
\hline 22 & 4.30 & 4.14 & 3.87 & 3.12 \\
\hline 23 & 3.94 & 4.17 & 3.34 & 3.24 \\
\hline 24 & 4.19 & 4.20 & 3.78 & 3.20 \\
\hline 25 & 4.39 & 3.92 & 3.89 & 3.01 \\
\hline Average & 4.68 & 4.98 & 4.00 & 3.73 \\
\hline P1 & 4.10 & 4.75 & 3.58 & 3.75 \\
\hline $\mathrm{P} 2$ & 4.69 & 4.21 & 3.78 & 3.58 \\
\hline Bulk & 4.11 & 3.97 & 3.35 & 3.21 \\
\hline $\begin{array}{c}\text { RLSD } \\
0.05\end{array}$ & 0.19 & 0.21 & 0.23 & 0.28 \\
\hline $\begin{array}{c}\text { RLSD } \\
0.01\end{array}$ & 0.25 & 0.28 & 0.30 & 0.37 \\
\hline
\end{tabular}

\section{CONCLUSION}

This study concluded that selection in segregating generations of the two wheat populations for higher yielding genotypes under Toshka condition were suitable for these populations to practice the direct selection for grain yield/plant. The family no. 15 had recorded the maximum values for grain and biological yield/plant in pop. 1, and the families no. 5 and 16 in pop. 2 had the same trait. According to the high estimates of heritability, selection in segregating generation for heading date, number of spikes/plant and grain yield/plant traits would be effective in obtaining genotypes earlier in heading and higher in grain yield than its corresponding parents. The 50 superior 
segregates selected from $\mathrm{F}_{3}$ families has been occurred due to selection of transgressive segregates from $\mathrm{F}_{2}$ evaluated plants and may be promoted to the $\mathrm{F}_{4}$ generation to produce promising and improved pure lines and/or used as useful germplasm for future bread wheat breeding programs under Toshka conditions.

\section{REFERENCES}

Ahmed, A.A.S., M.A. El-Morshidy, K.A. Kheiralla, R. Uptmoor, M.A. Ali and Naheif E.M. Mohamed (2014). Selection for drought tolerance in wheat population (Triticum aestivum L.) by independent culling levels. World J. Agric. Res., 2 (2): 56-62.

Al-Bakry, M.R.I. (2007). Glaucous wheat mutants. I. Agronomic performance and epicuticular wax content. Egypt. J. Plant Breed., $11(1): 1-9$.

Al-Naggar, A.M.M. and M.T. Shehab El-Deen (2012). Predicted and actual gain from selection for early maturing and high yielding wheat genotypes under water stress conditions. Egypt. J. Plant Breed., 16 (3): 73-92.

Al-Naggar, A.M.M., A.E.I. Ragab, S.S. Youssef and R.I.M. Al-Bakry (2004). New genetic variation in drought tolerance induced via irradiation and hybridization of Egyptian cultivars of bread wheat. Egypt. J. Plant Breed., 8: 353-370.

Al-Naggar, A.M.M., M.M. Atta, A.M. Shaheen and F. Al-Azab (2007). Gamma rays and EMS induced drought tolerant mutants in bread wheat. Egypt. J. Plant Breed., 11 (3): 135-165.

Al-Rawi, K.M. and A.M. Khalafalla (1980). In: "Design and Analysis of Agricultural Experiments". Dar Al-Kutub for Printing and Publishing, Mosul Univ., Iraq.

Blum, A., H. Poiarkova, G. Golan and J. Mayer (1983). Chemical desiccation of wheat plants as a simulator of post-anthesis stress. I. Effect on translocation and kernel growth. Field Crops Res., 6: 51.

Burton, G.W. (1952). Quantitative inheritance in grasses. Proc. $6^{\text {th }}$ Intercropping. Grassland Cong. 1: Chowdhury, N.H. 1991. Studies on quality of rice in Bangladesh. In: Proceeding of the workshop on chemical aspects of rice grain quality, IRRI, Philippines, p. 23-127.

El Ameen, T., A. Hossain and J.A. Teixeira da Silva (2013). Genetic analysis and selection for bread wheat (Triticum aestivum L.) yield and agronomic traits under drought conditions. Int. J. Plant Breed., 7 (1): 61-68.

El-Morshidy, M.A., K.A.A. Kheiralla, M.A. Ali and A.A. Said (2010). Response to selection for earliness and grain yield in wheat

Egyptian J. Desert Res., 69, Special Issue, 1-18 (2019) 
(Triticum aestivum L.) under normal and water stress conditions. Assiut J. Agric. Sci., 41: 1-23.

FAO, Food and Agriculture Organization of United Nations (2018). Statistical Database, Available online: http://www.fao.org.

Farshadfar, E., N. Mahmodi and A. Yaghotipoor (2011). AMMI stability value and simultaneous estimation of yield and yield stability in bread wheat (Triticum aestivum L.). Australian J. Crop Sci., 5 (13): 1837-1844.

Gomez, K.A. and A.A. Gomez (1984). In: "Statistical Procedures for Agriculture Research". John Wiley and Sons. Inc. New York, USA.

Ludlow, M.M. and R.C. Muchow (1990). A critical evaluation of traits for improving crop yield in water limited environments. Advances in Agronomy, 43: 107-153.

Memon, S., N. Iqbal, F. Zaman, S. Memon, M.A. Abro, G.H. Jatoi and A.R. Mangi (2018). Heritability estimates in $F_{2}$ segregating population in hexaploid wheat (Triticum aestivum L.). Pak. J. Biotechnol., 15 (3): 803-810.

Menshawy, A.M.M. (2007). Evaluation of some early bread wheat genotypes under different sowing dates: 1. Earliness characters. Egypt. J. Plant Breed., 11 (1): 25-40.

Patel, J.M., A.S. Patel, C.R. Patel, H.M. Mamrutha, S. Pradeep and Karen P. Pachchigar (2019). Evaluation of selection indices in screening durum wheat genotypes combining drought tolerance and high yield potential. Int. J. Curr. Microbiol. and App. Sci., 8 (4): 11651178.

Poehlman, J.M. and D.A. Sleper (1995). In: "Breeding Field Crops". Iowa State University Press, Ames, XV, 494 p.

Trethowan, R.M. and W.H. Pfeiffer (2000). Challenges and future strategies in breeding wheat for adaptation to drought stressed environments: A CIMMYT Wheat Program Perspective. In: Ribaut, J.M. and D. Poland (eds.). Molecular approaches for the genetic improvement of cereals for stable production in water-limited environments. A strategic planning workshop held at CIMMYT El Batan, Mexico, 21-25 June 1999. CIMMYT, Mexico DF, p. 45-48.

UNECA, United Nations Economic Commission for Africa, Addis Ababa; Global Environment Outlook (GEO) (2000), UNEO, Earth Scan, London, 1999, Population Action International. 


\section{الإنتخاب المنسب للمحصول في قمح الخبز لنقص الماء بتوشكي}

سعد محمد أحمد نصار قسم الأصول الور اثية، مركز بحوث الصحر اء، المطرية، القاهرة، مصر

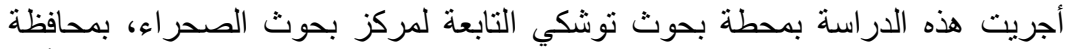

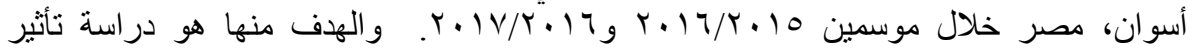

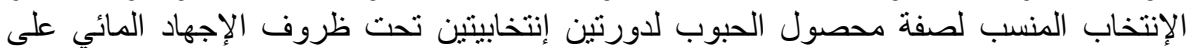

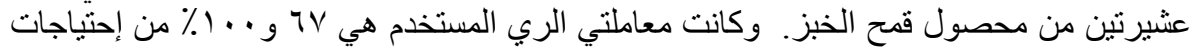

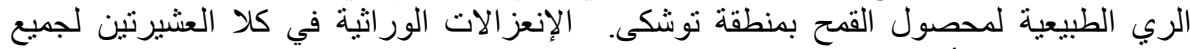

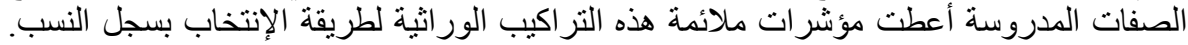

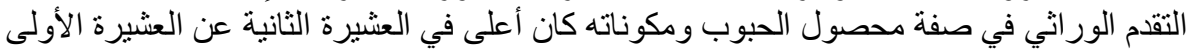

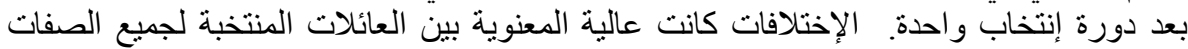

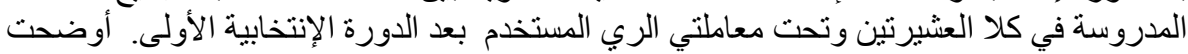

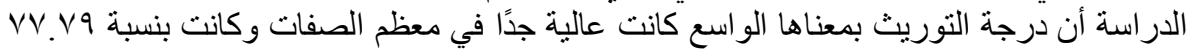

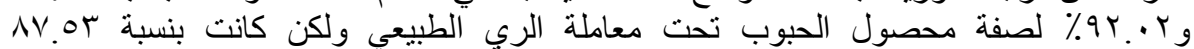

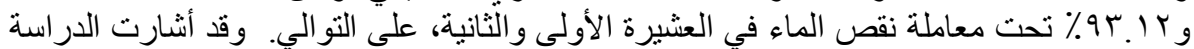

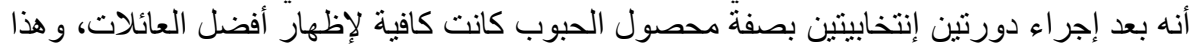

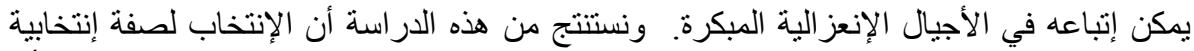

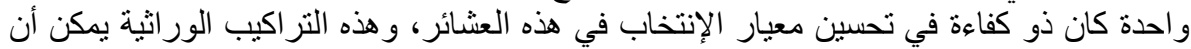
تستخدم كمصدر من مصادر تحمل الجفاف. تحان.

Egyptian J. Desert Res., 69, Special Issue, 1-18 (2019) 